УДК 373

DOI: $10.15330 /$ esu. $17.318-324$

\author{
Галина Білавич, \\ доктор педагогічних наук, професор, \\ ДВНЗ "Прикарпатсыкий національний \\ університет імені Василя Стефаника" \\ (м. Івано-Франківськ, Україна) \\ Halyna Bilavych, \\ Doctor of pedagogical sciences, Professor, \\ Vasyl Stefanyk Precarpathian national university \\ (Ivano-Frankivsk, Ukraine) \\ ifosuhcvas@gmail.com \\ Олег Довгий, \\ кандидат фізико-математичних наук, доцент, \\ ДВНЗ "Прикарпатський національний \\ університет імені Василя Стефаника" \\ (м. Івано-Франківськ, Україна) \\ Oleg Dovgyi, \\ Candidate of physical and mathematical sciences \\ $(\mathrm{PhD})$, Associate Professor, Vasyl Stefanyk \\ Precarpathian national university \\ (Ivano-Frankivsk, Ukraine) \\ olegdovgij@gmail.com
}

\section{Наталія Головчак,} студентка, ДВНЗ "Прикарпатський національний університет імені Василя Стефаника" (м. Івано-Франківськ, Україна)

Nataliia Holovchak,

Student, Vasyl Stefanyk Precarpathian national university (Ivano-Frankivsk, Ukraine)

natalia.golovchak04@gmail.com

\title{
РОЗВИТОК МОВНОЇ ОСОБИСТОСТІ МОЛОДШОГО ШКОЛЯРА НА УРОКАХ МАТЕМАТИКИ ТА ІНФОРМАТИКИ
}

\section{DEVELOPMENT OF LANGUAGE PERSONALITY OF JUNIOR PUPIL AT MATHEMATICS AND COMPUTER SCIENCE CLASSES}

Розвиток мовленнсвої культури молодиого иколяра - одне із завдань сучасной початкової иколи. Ця педагогічна й наукова проблема загострюється ще й тому, що до школи периокласники приходять загалом уже зі сформованими мовленнсвими навичками, які не завжди є правильними. Тому завдання вчителя - побачити мовленнєві негаразди, виправити їх, сформувати в дитини стійкі навички нормативного мовлення, зокрема й на уроках математики та інформатики. Для цього треба організувати мовленнєву діяльність учнів так, щоб процес розвитку культури усного мовлення відбувався комплексно, систематично.

Автори виокремлюють декілька умов успішного розвитку культури мовлення молодиих иколярів на уроках математики та інформатики. Периа умова -методика розвитку культури мовлення повинна враховувати такі ситуації, які б визначали 
мотивачію до вивчення мовленнсвих норм, ставили учня перед необхідністю використовувати нормативне мовлення, підвицувати власний рівень мовленнєвої культури, розиирювати лексичний запас, чути мовленисві негаразди свойх друзів $і$ бачити свої мовленнєві огріхи та вміти виправляти їх тоџо. Важливим у прочесі формування культури усного мовлення є приклад учителя, який повинен сам буди зразком носія високої мовленисвої культури, а також прикладом фаховості, який за будь-якої можливості нагадуватиме дітям про культуру мовлення, виправлятиме їхні помилки, дбатиме про формувания в них стійких умінь нормативного мовления. Ефективність процесу формування культури усного мовлення молодиих иколярів узалежнена від дочільно дібраних методів та прийомів, інноваційних форм роботи вчителя на уроці. Наступна умова - розвиток культури мовлення молодиих иколярів має відбуватися не тільки на уроках украйнськой мови чи літературного читання, а й на іниих уроках, зокрема математики та інформатики. Ідеться про створення відповідного екологічно мовленнсвого середовица, від якого залежить, наскільки різноманітним, багатим, правильним буде мовления дитини.

Ключові слова: культура мовлення, молодиий иколяр, уроки математики та інформатики, мовні помилки, наголочувания слів.

Development of the speech culture of junior students is one of the tasks of the modern elementary school. This pedagogical and scientific problem is exacerbated also by the fact that generally first-graders come to school with already developed incorrect language skills. Therefore, the teacher's task is to recognize speech problems, correct them, form child's stable skills of normative speech, including during the classes of mathematics and computer science. For this purpose it is necessary to organize the speech activity of students so that the process of development of the culture of oral speech occurs in a comprehensive and systematic way.

We highlight several conditions for successful development of the speech culture of junior students during the classes of mathematics and computer science. The first condition: the methodology of developing a culture of speech should take into account situations that would determine the motivation to learn speech norms, put the student before the need to use normative speech, increase their own level of speech culture, expand the lexical stock, recognize speech problems of others and be able to correct them etc. It is important for a teacher to be a role model of high speech culture, as well as an example of professionalism, which, whenever possible, will remind children about the culture of speech, correct their mistakes, and take care of forming stable norms. The effectiveness of the process of forming the culture of oral speech of younger students depends on appropriately selected methods and techniques, innovative forms of teacher's work in the classroom.

The next prerequisite is that the development of the language culture of junior students should take place not only in the Ukrainian language or literary reading classes, but also during other lessons, such as mathematics and computer science. It means creating a friendly speech environment that will determine diversity, richness, and correctness of baby's speech.

Key words: speech culture, junior student, mathematics and computer science classes, language mistakes, word pronunciation.

Постановка проблеми. 3-поміж чинників, що здійснюють вплив на розвиток мовної особистості молодшого школяра і сприяють оволодінню мовленнєвою обізнаністю, є мовне середовище. Рівень культури мовлення зростаючої особистості залежить від сім'ї, закладів освіти, прагнення до самовдосконалення, від мовного соціуму, у якому перебуває дитина. Учені, педагоги-практики сьогодні із занепокоєнням зазначають, що рівень володіння культурою мовлення молодших школярів вимагає бути кращим, мовлення учнів початкових класів $\epsilon$ збідненим, часто неграмотним, засміченим суржиком, росіянізмами, діалектизмами тощо. 
Мета сучасної освіти полягає не в тому, щоб учень знав якомога більше, а в тому, щоб він умів діяти і розв'язувати проблеми за будь-яких життєвих ситуацій. Однією зі сформованих компетенцій молодшого школяра, що дозволяє розв'язати ці завдання, $є$ культура мовлення. I саме початкова школа $\epsilon$ тим періодом навчання, протягом якого учні намагаються опановувати норми української літературної мови, повинні навчитися використовувати мовні засоби відповідно до цілей і завдань мови, уміти доцільно ними послуговуватися. У цьому складному процесі провідна роль відводиться вчителеві, який має стати для дітей зразком мовленнєвої культури, відтак допомогти їм засвоїти вимоги до мовленнєвої діяльності, працювати над збагаченням лексичного запасу, дбати про нормативність мовлення.

Незважаючи на значну увагу до мовленнсвої культури молодших школярів, ці завдання сьогодні розв'язуються не в повному обсязі, оскільки мовне середовище (сім'я, спілкування 3 однолітками, ЗМІ, мережа Інтернет, інші соцмережі, у яких перебуває дитина), а також життя за стінами школи не завжди є зразком високої мовленнєвої поведінки. Більшість школярів $є$ носіями збідненої, ненормативної української мови, яка 3 їхніх вуст лунає одноманітною i невиразною, зазвичай i неправильна з точки зору літературної норми. Ці та інші суперечності вказують на необхідність розв'язання проблеми: які педагогічні умови створити, які механізми необхідно залучити для ефективного здійснення процесу формування культури мовлення молодших школярів в освітньому процесі початкової школи.

Одне із завдань сучасної школи - формування культури усного мовлення молодших школярів. Ця педагогічна й наукова проблема загострюється ще й тому, що до школи першокласники приходять загалом уже зі сформованими мовленнєвими навичками, які не завжди $є$ правильними. Тому завдання вчителя - побачити мовленнєві негаразди, виправити їх, сформувати в дитини стійкі навички нормативного мовлення, зокрема й на уроках математики та інформатики. Для цього треба організувати мовленнєву діяльність учнів так, щоб процес розвитку культури усного мовлення відбувався комплексно, систематично.

Аналіз останніх досліджень і публікацій. Протягом останніх десятиріч проблему формування культури усного мовлення особистості школяра розглядали О. Авраменко, Н. Бабич, А. Богуш, М. Вашуленко, А. Коваль, В. Кононенко, Т. Котик, М. Пентилюк, О. Савченко, М. Стельмахович та ін. Наукові напрацювання 3 проблеми формування культури усного мовлення молодших школярів продиктовані вимогами сьогодення. Нова українська школа, Закон про мову, ухвалений 2019 року, інші державні документи актуалізують потребу виховання національно-мовної особистості школяра, який здатний грамотно висловлювати свої думки, продукувати ідеї адекватними мовними засобами, бути творчою, ініціативною, інтелігентною людиною, патріотом України. Без високого рівня мовленнєвої культури цього досягти досить проблематично.

Мета статті - проаналізувати стан мовленнєвої культури молодших школярів на уроках математики та інформатики, обгрунтувати педагогічні умови формування культури усного мовлення учнів початкових класів.

Виклад основного матеріалу. Спостереження за мовним педагогічним середовищем у межах низки івано-франківських шкіл (2016-2019 рр.) дали підстави для висновку, що рівень українського мовлення молодших школярів (як усного, так i писемного) на уроках математики та інформатики є здебільшого середній, а то й низький. Аналіз результатів дослідження засвідчив, що великий відсоток помилок (понад 90\%) зумовлений інтерферентними явищами внаслідок інтенсивного впливу 
російської мови, якого постійно зазнає українська мова (у ділянці терміносистеми, доборі потрібних термінів, умінні правильно ними оперувати, коректно перекласти українською той чи інший термін з російської мови, урешті, зредагувати текст). Це пов'язано з тим, що молодші школярі грають у російськомовні ігри, слухають російськомовні додатки на телефонах та комп'ютерах, переглядають мультфільми, російськомовні канали в ютубі, слухають російськомовні пісні, переглядають низькопробні в мовному сенсі блоги тощо. Також відстежуємо таке явище, коли учні початкової школи, листуючись у своїх дитячих групах, абсолютно не зважають на норми сучасної української мови, повністю нехтують знаннями в галузі нормативного мовлення. Для них ненормативне мовлення стає нормою. I тільки на уроках української мови вони контролюють (за допомогою вчителя) власне мовлення, прагнуть зробити його більш досконалим.

Важливо зазначити, що великий відсоток молодших школярів (87\%) “ніколи не задумався над тим, щоб у соцмережах, а також телефонічно спілкуватися правильно", 79\% респондентів вважають “мову Інтернету досконалою" в мовному сенсі, тільки $7 \%$ школярів спроможні зафіксувати помилки в соцмережах, 52\% респондентів стверджують, що “так всі спілкуються".

Зазначимо, що інтерферентні явища наявні не тільки в соцмережах, а й у багатьох освітніх джерелах. Це є великою проблемою, оскільки навчальна література $\epsilon$ для молодших школярів зазвичай зразками для наслідування. Ми зафіксували низку мовленнєвих помилок, які тиражуються в навчальних виданнях (див. [3; 4; 5]).

Певну потенційну загрозу для створення нормативного мовного середовища мають і сайти (на жаль, не $є$ винятком тут і навчальні та розвивальні матеріали, уміщені на них), які рясніють мовними помилками, змістовими неточностями, де, до прикладу, героями українських народних казок $€$ “іноземці". Такі інформаційні видання перекручують моральні цінності дітей, абсолютно не сприяють вихованню в них національних почуттів. А наявність у них численних помилок (граматичних, пунктуаційних, стилістичних тощо) відтак закономірно переростають у мовні негаразди та покручі, які трапляються у шкільних підручниках для дітей молодшого шкільного віку [2; 6], тут наявні ненормативні росіянізми, порушення орфографічних, пунктуаційних норм тощо [5], вперте ігнорування укладачами навчальних видань та видавцями літери г, кличного відмінка іменників, відсутність апострофа та ін. У зв'язку із недолугим перекладом з російської мови молодші школярі знайомляться не 3 питомими українськими лексемами, а з лексичними анормативами на кшталт: “відкрий книжку”, “брат старше сестри”, “розстав по алфавіту”, “підбери спільнокореневі слова", “розв’яжи по зразку”, “два ведмедя”, “слідуюче завдання”, "вірне рішення" та ін.

За результатами аналізу навчально-методичного забезпечення навчальних курсів для початкових класів зазначимо: українське підручникотворення переживає складний етап свого розвитку, спричинений 3-поміж іншого і тим моментом, що мова підручників не завжди $є$ високоавторитетним зразком літературності. Не $\epsilon$ винятком i підручники 3 інформатики та математики. Типовими помилками $\epsilon$ вживання росіянізмів - мовних покручів, які здебільшого спричинені недолугим перекладом (адаптацією до української звуковимови) імен казкових героїв та персонажів мультфільмів (Маша, Лунтік, Фіксік, Елзік та ін.; правильно: Марійка, Лунтик, Фіксик, Елзик). Виразною є тенденція до використання українських імен та питомих українських зменшувально-пестливих форм імен дітей, людей, кличок тварин тощо, натомість автори підручників, посібників, навчальних матеріалів 
послуговуються російськими розмовними варіантами імен на кшталт Ваня, Маша, Міша, Даша й под., що неприпустимо, позаяк такі форми суперечать словотвірним нормам сучасної української літературної мови [2].

На жаль, низку порушень усного мовлення ми зафіксували в учителів, які навчають дітей математики та інформатики в початковій школі (в даному випадку - y цььому випадку, оточуюче середовище - довкілля, розкрити очі - розплющити очі, у цілому - загалом, більша половина класу - більшість класу, вирішиила задачу розв 'язала задачу, виключити світло - вимкнути світло та ін.). За таких умов для нас важливим було з'ясувати, як ставляться самі вчителі до проблеми формування культури мовлення учнів початкових класів. Відповіді на запитання анкети були певним чином несподіваними для нас: понад 50\% учителів відповіли, що “не мають часу стежити за мовленням учнів, тому що багато дітей i багато навчального матеріалу відводиться на урок", 89\% учителів зазначили, що таку роботу обов'язково проводять на уроках української мови, особливо на уроках зв'язного мовлення, "згідно з програмою", 67\% - на "відповідних уроках 3 літературного читання”, незважаючи на тему уроку, лише 48\% педагогів зазначили, що прагнуть звертати увагу на мовлення молодших школярів, за будь-якої нагоди, зокрема й на уроках математики та інформатики, намагаються виправляти мовленнєві помилки, більшість проводять таку роботу епізодично.

Учитель початкових класів мусить володіти високим рівнем мовленнєвої культури, оскільки він є зразком для наслідування своїм вихованцям. Під час уроків математики та інформатики в початкових класах ми зафіксували десятки лексичних анормативів у мовленні вчителя та школярів. Подаємо найтиповіші 3 них: дане завдання, вирішити задачу, виключити комп'ютер, наступні автори, у програмі було задіяно 120 чоловік, біля 20 \%, навколишне середовище, вирішили вірно, 10 чоловік, ще складає 8\%, характерний учневі, властивий для школяра, притаманний для оитини, самий вищий рівень, вищий середнього, розставити по алфавіту, дані приведено в таблиці, а іменно, приймати міри, учбовий процес, $і$ так дальие, ми вияснили, на протязі учбового року, учбові програми, відносини між учнями, запобігати помилок, англічани, приводити приклад, у иілому, в даному випадку, у більиості, заслуговуе високої оцінки, відношення до навчання учнів, вірну відповідь дали на питання, у твоїй відповіді зустрічаються помилки, навчатися математиці, кращий учень, задавати питання, виконує велику роль, приймати до уваги, у порівнянні з минулим роком, недопустимо, повільно грузиться та десятки ін. На основі цих помилок можна укласти словничок нормативного слововживання для молодших школярів.

За результатами опитування вчителів початкових класів та інформатики іванофранківських шкіл, лише $43 \%$ педагогів зазначили, що епізодично проводять корекційну роботу щодо виправлення мовленнєвих помилок. Іншим мовним недоліком мовлення майбутніх педагогів залишається суржик (87 \% респондентів): бувший (колищній), командировка (відрядження), блінчики (млиниі), іменно (а саме), на кінець (отюе), опреділити (визначити), примінити (застосувати), вияснити (з'ясувати), звідки витікас (звідки випливас), в кінці кінців (зрештою, нарешті) та десятки інших. У 32 \% мовців ми виявили таке слововживання, як тавтологія (напр., у місяці лютому тощо). Для уникнення цієї проблеми необхідно використовувати синоніми, котрі дають змогу в кожному конкретному випадку дібрати відповідне слово для найточнішого вираження думки. 
Ми зафіксували використання стилістично невиправданих словоформ (величезна більиість дослідників замість значна частина дослідників або просто більиість дослідників, більиа частина учнів замість більиість учнів та ін.), природнього середовища замість природного середовища, завдяки помилці замість через помилку, часткові випадки замість окремі випадки).Наші респонденти припускаються таких морфологічних помилок: неправильне утворення відмінкових форм іменників, прикметників, числівників, займенників (семи учнями замість сімома (сьома) учнями; зворотнього зв'язку замість зворотного зв'язку й ін.); неправильне визначення граматичного роду іменників (головна біль (ж.р.) замість головний біль (ч.p), ін); неправильне утворення ступенів порівняння прикметників і прислівників (більи складніша задача замість більи складна задача, найскладніша задача, найбільи ефективніие замість найбільи ефективно та ін.); неправильна словозміна числівників (від n'ятидесяти до шестидесяти відсотків замість від n'ятдесяти до шістдесяти відсотків); порушення закономірностей сполучуваності дробових числівників з іменниками (отримали 5,2 бали замість отримали 5,2 бала); порушення категорій стану, особи дієслів (хотять замість хочуть); неправильне утворення дієслівних форм (говорючи, боряться замість говорячи, борються) тощо. Найтиповішими помилками у вживанні займенників є: нi одного разу замість жодного разу, їх замість їхній, ні в якому разі замість у жодному разі, виявили свої здібності замість виявили власні здібності. Мовні недоліки зустрічаються і при вживанні сполучників. До прикладу, у той час замість тоді як, у силу того що замість через те щзо, так як замість оскільки, на протязі часу замість протягом часу й ін. Іншими поширеними помилками у вживанні прийменників $\epsilon$ : раз в місяџь замість раз на місяць, у изьому роиі замість цуього року, за браком часу замість через брак часу.

Як показали результати нашого дослідження, молодші школярі на уроках математики та інформатики найбільше припускаються помилок у наголошуванні слів. За таких умов радимо вчителям на уроках математики та інформатики звертати увагу на нормативність наголошування слів. Також доречно буде укладати словничок наголосів “Наголошуймо українською правильно!", куди вносити слова, у яких найчастіше учні порушують наголос. Роботу із цими словами можна проводити практично на кожному уроці, улаштовуючи “Акцентологічні хвилинки”, метою яких є запам'ятовуання наголосу у словах (випадок, кілометр, новий, старий, дециметр, чисельник, дробовий, добуток, фаховий, легкий, важкий, товстий, середина, беремо, роблю, валовий, вісімдесят, чотирнадиять, одинадиять, дошка, иести, везти, ознака, виразний, читання, навчання, видання, правопис, перепис, копійки, ластівки, вчительки, порядковий, предмет, приятель, подруга, черствий, дочка, жила, було, двірник, цемент, квартал, легкий, вісімдесят, вісімсот, відповіла, розповісти, котрий, документ, зроблю, загадка та ін.).

Висновки та перспективи подальших дослідження. Отже, є нагальна потреба в удосконаленні умінь і навичок молодших школярів правильного, безпомилкового вираження думок українською літературною мовою на уроках математики та інформатики. Відповідно вчителі мають постійно дбати про підвищення рівня культури мовлення як учнів, так і власної мовленнєвої культури, а саме: не використовувати у своєму мовленні суржику, сленгу, англіцизмів, росіянізмів; не нехтувати формами кличного відмінка іменників; не вживати невластиві українській мові пестливі форми - Анічка, Сашенька, Валічка, Сєрьоженька, Кіріл, Нікіта, Ваня, Коля, Лєночка, Андрюша тощо; вживати загальновідомі слова, уникати двозначності, обходитися без запозичень там, де можна скористатися питомим словом (на лек- 
сичному рівні); не розтягувати занадто фрази, не розривати думку довгими вставками, обмежувати кількість підрядних речень, не захоплюватися пасивними зворотами, дотримуватися природного прямого порядку слів (на синтаксичному рівні) тощо.

3-поміж умов успішного розвитку культури усного мовлення молодших школярів на уроках математики та інформатики виокремлюємо декілька. Перша умова - методика розвитку культури мовлення повинна враховувати такі ситуації, які б визначали мотивацію до вивчення мовленнєвих норм, ставили учня перед необхідністю використовувати нормативне мовлення, підвищувати власний рівень мовленнєвої культури, розширювати лексичний запас, чути мовленнєві негаразди своїх друзів і бачити свої мовленнєві огріхи та вміти виправляти їх тощо. Важливим у процесі формування культури усного мовлення $є$ приклад учителя, який повинен сам буди зразком носія високого гатунку мовленнєвої культури, а також прикладом фаховості, який за будь-якої можливості нагадуватиме дітям про культуру мовлення, виправлятиме їхні помилки, дбатиме про формування в них стійких умінь нормативного мовлення. Ефективність процесу формування культури усного мовлення молодших школярів узалежнена від доцільно дібраних методів та прийомів, інноваційних форм роботи вчителя на уроках. Наступна умова - розвиток культури мовлення молодших школярів має відбуватися не тільки на уроках української мови чи літературного читання, а й на інших уроках, зокрема математики та інформатики. Ідеться про створення відповідного екологічно мовленнєвого середовища, від якого залежить, наскільки різноманітним, багатим, правильним буде мовлення дитини. Під таким мовленнєвим середовищем маємо на увазі не тільки шкільне мовне довкілля, а й той мовленнєвий простір позашкільних закладів, у яких перебуває дитина поза школою. Велика роль у цьому процесі належить батькам, однак цей аспект проблеми не став предметом нашого дослідження через обмежені обсяги наукової роботи. Цей напрям дослідження неодмінно буде предметом наших

\section{Література}

1. Бабич Н. Д. Основи культури мовлення. Львів : Світ, 1990. 232 с.

2. Білавич Г. Анормативні інтерфереми в навчальній літературі для дітей дошкільного та молодшого шкільного віку. Обрії. 2017. № 1(44). С. 4-7.

3. Білавич Г., Стамбульська Т. Говорімо українською мовою правильно! Івано-Франківськ, 2012. $60 \mathrm{c}$

4. Білавич Г., Лисечко Т., Стамбульська Т. Наголошуймо правильно! Івано-Франківськ, 2013. $135 \mathrm{c}$.

5. Білавич Г., Савчук Б. Українське наукове мовлення в контексті наукової діяльності майбутніх педагогів. Інноватика у вихованні. Збірник наукових праць. 2017. Випуск 6. С.67-75.

6. 153 помилки на 149 сторінках. Тернопільські педагоги перевірили підручник 3 математики. URL: http:// ua.korrespondent.net/.../1613362-153-pomilki-na-149-storinkah-ternopilski-pedagogiperevirili-pidruchnik-z-matematiki

\section{References}

1. Babych N. D. Osnovy kultury movlennia. Lviv : Svit, 1990. 232 p.

2. Bilavych H. Anormatyvni interferemy v navchalnii literaturi dlia ditei doshkilnoho ta molodshoho shkilnoho viku. Obrii. 2017. № 1(44). P. 4-7.

3. Bilavych H., Stambulska T. Hovorimo ukrainskoiu movoiu pravylno! Ivano-Frankivsk, 2012. $60 \mathrm{p}$.

4. Bilavych H., Lysechko T., Stambulska T. Naholoshuimo pravylno! Ivano-Frankivsk, 2013. 135 p.

5. Bilavych H., Savchuk B. Ukrainske naukove movlennia v konteksti naukovoi diialnosti maibutnikh pedahohiv. Innovatyka u vykhovanni. Zbirnyk naukovykh prats. 2017. Vypusk 6. P.67-75.

6. 153 pomylky na 149 storinkakh. Ternopilski pedahohy pereviryly pidruchnyk z matematyky. URL: http:// ua.korrespondent.net/.../1613362-153-pomilki-na-149-storinkah-ternopilski-pedagogi-pere virili-pidruchnik-z-matematiki Babych N. D. Osnovy kultury movlennia. Lviv : Svit, 1990. 232 p.

Одержано статтю: 21.10.2019

Прийнято до друку: 11.11.2019 